\title{
O SEXO E A MORTE DOS TOUROS. A CONTROVÉRSIA TAURINA E O OCASO DA TRAGÉDIA
}

\author{
Oscar Calavia Sáez* \\ Universidade Federal de Santa Catarina - Brasil
}

Resumo: $O$ artigo explora as claves simbólicas da tourada espanhola e do movimento antitaurino que postula a sua erradicação. Em que pese o acirramento do seu antagonismo, "taurinos" $e$ "antitaurinos" têm em comum algumas diferenças com o paradigma "moderno" de separação natureza/cultura (ou humano/animal) e elaboram, cada um por seu lado, uma identificação entre os humanos e os seus animais de escolha. Essa identificação - que no caso das touradas remete ao tema clássico do sacrifício - põe em jogo noções sobre gênero e sexualidade.

Palavras-chave: animalismo, gênero, sexualidade, touradas.

Abstract: I explore the symbolic keys of the Spanish bullight, as well as those embedded in the growing anti-bullfight movement. Notwithstanding their rampant antagonism, bullfight lovers and bullfight haters share a stand against the "modern" nature/ culture (animal/human) divide. They both build, albeit in a divergent fashion, an identification between the humans and their chosen animals. This identification, that in bullfight redirects to the classical anthropological theme of sacrifice - is grounded on sex and gender conceptions.

Keywords: animalism, bullfight, gender, sexuality.

As touradas espanholas levam séculos sendo motivo de polêmica; bem mais tempo do que levam sendo um símbolo ou uma festa nacionais. Mas essa polêmica tem se acirrado contemporaneamente até se tornar a mais intensa (no sentido emotivo e no sentido semântico) de todas as que envolvem direitos animais. A opinião antitaurina tornou-se majoritária, sobretudo entre a população espanhola mais jovem e urbana. Junto com os argumentos em comum com outros movimentos

* Contato: occs@uol.com.br

Horizontes Antropológicos, Porto Alegre, ano 23, n. 48, p. 151-170, maio/ago. 2017 http://dx.doi.org/10.1590/S0104-71832017000200007 
animalistas, ela usa um léxico agressivo - atraso, barbárie, selvajaria, primitivismo, incultura, aberração, irracionalidade - que alveja uma identidade e uma tradição nacionais controversas. A tendência antitaurina alimenta e se alimenta das tensões entre os nacionalismos centrais e periféricos, ${ }^{1}$ e entre o catolicismo e uma tendência laicista com tintas crescentemente anticlericais ou antirreligiosas. Na polêmica sobre os touros há muito mais do que uma controvérsia animalista. O touro de que falamos não é apenas um animal empírico, ele simboliza tudo aquilo que diz simbolizar e muito mais que não consegue se exprimir de outro modo.

\section{Contextos não ditos}

Começarei num ponto muito periférico do mundo dos touros, tratando de um romance taurino, Los mozos de Monleón, que nunca foi objeto de muita atenção. Em espanhol, a palavra "romance" designa um poema narrativo (e cantado) em versos octossílabos, que foi o gênero por excelência da épica popular espanhola. Recolhidos em coletâneas desde o Renascimento, os romances continuavam a ser garimpados por folcloristas e filólogos em inícios do século XX, quando várias versões de Los mozos de Monleón foram anotadas, com sua música. Vejamos uma delas:

Los mozos de Monleón se fueron a arar temprano

para dir a la corrida [no original, joriza; corrida: tourada]

y remudar con despacio; [remudar: trocar de roupa]

al hijo de la viuda [no original, veyuda]

el remudo no le han dado. [a mãe lhe nega a roupa limpa]

- Yo a la corrida he de ir

aunque lo busque emprestado.

- Permita Dios si allá vas

que te traigan en un carro, [carro: charrete, obviamente]

las abarcas y el sombrero [abarca: tipo de calçado simples, uma sola de esparto atada com fitas]

\footnotetext{
1 As touradas têm sido recentemente proibidas pelo governo autônomo da Catalunha, não sem críticas de quem considera hipócrita a manutenção dos correbous, festas rurais taurinas porém catalãs. Embora o antitaurinismo esteja inserido também no abertzalismo basco, o forte enraizamento das touradas em algumas cidades bascas tem impedido que se tomem lá medidas semelhantes.
} 
de los indiestos colgando! [indiestos: estacas laterais da carroça, que seguram a carga]

Se cogen los garrochones, [garrochón: um tipo de lança usada na tourada] se fueron la nava abajo, [nava: terra plana e sem árvores]

preguntando por el toro,

y el toro ya está encerrado.

En el medio del camino

al vaquero se encontraron.

$-¿$ Cuánto tiempo tiene el toro?

- El toro tiene ocho años. [os touros costumam ser lidiados com mais ou menos cinco]

Muchachos, no entréis a él;

mirar que el toro es muy malo,

que la leche que mamó

se la di yo por mi mano.

- Si nos mata que nos mate,

ya venimos sentenciados.

Manuel Sánchez llamó al toro,

nunca lo hubiera llamado:

por el pico de una abarca

toda la plaza arrastrando.

- Compañeros, yo me muero;

amigos, yo estoy muy malo;

tres pañuelos tengo dentro [tenta estancar a hemorragia com lenços]

y este que meto son cuatro.

Al rico de Monleón

le piden los gües y el carro. [gües: bois]

A la puerta la viuda

arrecularon el carro.

- Aquí tenéis vuestro hijo

como lo habéis demandado.

A eso de los nueve meses

la madre sale bramando;

los vaqueriles arriba,

los vaqueriles abajo,

preguntando por el toro,

y el toro ya está enterrado

(Versão de G. Menéndez Pidal, 1935 apud Puerto, 1988).²

2 Nessa transcrição me permiti modificar alguns termos dialetais, tais como veyuda $=$ viuda ou joriza $=$ corrida . 
Los mozos de Monleón foi uma das peças populares que Federico García Lorca publicou em partitura harmonizada para piano, e nessa versão alcançou certa difusão na discografia erudita. É curioso que um poeta que flertou com o surrealismo, como Lorca, tenha simplificado o romance eliminando a sua coda, fazendo-o acabar no verso "como lo habéis demandado" e evitando assim o seu segmento mais obscuro. A única análise que conheço desse romance (Puerto, 1988) o define como uma tragédia de confronto entre a autoridade da mãe e a rebeldia do filho, que deseja afirmar a sua condição de homem na tourada, mas perece vítima da maldição materna. Os conflitos entre gerações - alegorias de uma tensão geral entre tradição e modernidade - foram temas caros às vanguardas literárias espanholas do século XX; e o castigo fatal de filhos desobedientes já era um tema muito frequente do romancero popular. Mas essa leitura é tão incompleta como a versão de Lorca.

Essa exclusão dos últimos seis versos aponta a dificuldade de assimilar seu conteúdo. A mãe de Manuel Sánchez, em lugar de sair presto a conferir o resultado de sua maldição, aparece apenas nove meses depois (um chavão de oito sílabas a que os romances recorriam para aludir a um nascimento), como se o desfecho da tragédia tivesse sido uma fecundação, e não uma morte. ${ }^{3}$ Ela reaparece em cena não chorando e se lamentando, mas bramando como os bovinos, percorrendo de um lado a outro os currais, e procurando não seu filho Manuel Sánchez, mas "o touro" - que já está "enterrado", outro dado estranho porque o destino dos touros mortos não é a sepultura, mas o consumo. Bem antes no romance, o vaqueiro avisa aos jovens que se abstenham de participar na tourada: Manuel Sánchez, o filho maldito da viúva, se enfrenta com um touro órfão (ele foi amamentado por mãos humanas, as do vaqueiro).

Que fazer com isso tudo? Esse tipo de relatos em que matador e vítima trocam seus papéis, em que um humano reaparece em forma de animal, em que uma imolação equivale a uma gravidez, e em que uma viúva age levada por algo que está mais para ciúme de amante que para amor materno, se encontram com frequência nesse mundo pagão que a antropologia sempre frequentou, mas não, pelo menos à primeira vista, no cristão campo de Salamanca em que o romance foi recolhido. ${ }^{4}$ Ninguém, nem os camponeses

\footnotetext{
Outra versão reproduzida por Puerto acrescenta alguns versos em que um padre confere os últimos sacramentos a Manuel, e a viúva desmaia ao ver o cadáver do filho, mas mantém o resto da conclusão.

4 Diga-se de passagem, a vontade de entender a cultura popular espanhola como "realista" - isto é, desprovida de fantasias pagãs - foi por longo tempo uma constante desse campo de estudos.
} 
nem os escassos folcloristas que têm se ocupado de sua tradição, tem destilado nada a partir desses enigmas, de modo que toda a secção final do romance tem a consistência dos lapsos e dos sonhos. Mas é precisamente nessa condição sub-reptícia, quando algo que se transmite no relato passa a ser um não dito no metarrelato, que a atenção a um mito pode fazer diferença: ele fala sobre o que é de praxe deixar na sombra. Para encontrar um comentário adequado desse mito devemos passar desse mundo das touradas rurais para o outro, bem mais conhecido, das touradas profissionais.

\section{Interpretações antropológicas}

O mundo das touradas tem uma vasta vertente erudita, ${ }^{5}$ que se estende da poesia à história ao ensaio, e no qual a antropologia tem um papel menor. Não faltam estudos antropológicos sobre a infinita variedade do mundo taurino rural, e sobre o seu enraizamento arcaico, mas o mundo das touradas profissionais tem interessado pouco à antropologia profissional. A peça mais famosa a elas dedicada pode ser um ensaio de Julian Pitt-Rivers (1984), ${ }^{6}$ que - sem recorrer a esse rótulo - encaminhou o tema das touradas para os estudos de gênero. A tourada é, diz ele, tão obviamente sacrificial - veja-se o estilo sacralizante de todos os detalhes da tourada, muito alheio ao de um espetáculo esportivo - que faz desaparecer uma questão central: qual seria o destino desse sacrifício? Para Pitt-Rivers, seria o de conciliar a relação agônica entre os sexos própria da cultura mediterrânea. ${ }^{7}$ A tourada põe essa conciliação em mãos de um oficiante, o torero, que na festa aparece inicialmente como sacerdote-sacrificador, transforma-se depois numa mulher sedutora e vai se

\footnotetext{
5 O mundo das touradas organiza uma cultura peculiar e enormemente intrincada, que abrange desde taxonomias da cor da pelagem dos touros ou da forma dos seus chifres a uma jurisprudência do ritual, passando por elaborações históricas ou filosóficas e debates com o antitaurinismo. Uma grande quantidade de informações contidas neste artigo procede do saber do autor como "nativo" (embora muito longe de ser um aficionado ou um especialista). Mas todas elas podem ser conferidas em revistas e livros especializados, e na enciclopédia Los toros de José M. Cossio, publicada em 12 volumes de 1943 a 1996, que teve ainda em 2007 uma edição popular de 30 volumes (Cossio, 2007).

6 A versão que utilizo é uma posterior (Pitt-Rivers, 2002), aparecida numa revista taurina; uma edição crítica do artigo original, que acrescenta outros materiais de interesse.

7 Bem resumida por um texto de Germaine Tillion (2000, p. 53, tradução minha), tratando de sua versão marroquina: as mães "se sujeitam aos seus filhos e sujeitam as suas filhas, mas inculcando aos dois com aplicação o terror do outro sexo: doravante, os filhos desconfiarão de todas as mulheres (salvo de sua mãe) enquanto as filhas terão medo de todos os homens, e (também) do seu pai”.
}

Horizontes Antropológicos, Porto Alegre, ano 23, n. 48, p. 151-170, maio/ago. 2017 
retransformando em homem até chegar ao momento do sacrifício em que a espada penetra numa ferida prévia do touro, comparável a uma vagina aberta. A interpretação de Pitt-Rivers pode ser exotizante e excessiva, especialmente nesse ponto final, mas toda ela, em conjunto, alude a associações simbólicas facilmente perceptíveis, a uma sexualização muito explícita dos ingredientes da festa. As touradas, segundo Pitt-Rivers, equilibrariam a relação agônica entre o masculino e o feminino: constituiriam assim um desses rituais de têmpera funcionalista, capazes de resolver no plano das fantasias as tensões irresolúveis da vida cotidiana.

A minha interpretação segue as linhas gerais da interpretação de PittRivers, e de Delgado Ruiz - à qual aludirei mais tarde -, que a revisou parcialmente. Mas o faz seguindo caminhos paralelos: aproveitando alguma de suas observações, acrescentando outras, e se desmarcando de sua conclusão.

É explícito para os nativos, taurinos ou antitaurinos, que as touradas são uma encenação da masculinidade. A associação do touro com a virilidade não precisa ser detalhada, mas o é em todos os terrenos, da retórica ao artesanato à culinária. O torero, da sua parte, põe em jogo todo o repertório masculino: coragem física, desprezo do perigo e da dor, domínio, sobranceria. Não apenas na arena: o torero seria um objeto eminente de desejo feminino. De um desejo perigoso, pois casar com um torero condena a um sofrimento polivalente (apenas superado por quem é ao mesmo tempo - algo nada incomum - esposa e mãe de torero). Uma norma não escrita das touradas veda a presença da esposa do matador no espetáculo, de mau agouro; e as ficções poéticas - sem excesso de fantasia - sempre outorgam a este uma ou várias amantes, sobre as quais não pesa esse tabu. A presença e a atitude das mulheres na tourada são, por assim dizer, marginais à sua gramática e essenciais à sua pragmática. Elas não têm papel nenhum no rito, mas a sua presença - e às vezes seu entusiasmo explicitamente tingido de erotismo - enfatiza o sentido da atuação do torero.

Não há como negar essa glorificação da masculinidade que aparece em primeiro plano; mas ela é apenas um elemento de um complexo em que há outras associações contrárias. A começar pelo mais visível: o traje do torero, elaborado segundo uma moda do século XVIII - quando as touradas foram regulamentadas na sua forma atual - tomou mais tarde conotações femininas. Pitt-Rivers não duvidou à hora de definir o torero como um travesti - de fato, tem sido por vezes fonte de inspiração para a moda feminina espanhola. Exatamente o mesmo pode se dizer das suas posturas, passos e gestos, 
e de toda a técnica e a apresentação corporal do torero. Sem que haja, que eu saiba, normas explícitas a esse respeito, a ideia de um torero barbado é incongruente; pelo contrário, é compulsório o uso de uma coleta - pequeno rabo-de-cavalo ou coque -, signo do torero na ativa. Em épocas em que esse arranjo de cabelo era intolerável para um homem, a coleta podia consistir num aplique colocado na nuca do torero apenas para o momento da tourada.

De um modo mais sutil porém mais contundente, o vocabulário da tourada (especializado e extensíssimo), tem sido uma fonte sempre disponível do vocabulário da sedução. Praticamente qualquer termo e qualquer evento da tauromaquia pode se aplicar à descrição do encontro erótico entre homem e mulher - dentro de uma concepção mal adaptada, com certeza, à ética amorosa atual. Isso, aliás, de um modo simétrico: mulher e homem podem, nesse jogo verbal, ocupar igualmente a posição do touro. ${ }^{8} \mathrm{Na}$ arena, frente ao touro, o torero não está em funções de macho: sua ação é sempre mínima, sutil, aparentemente passiva; ele provoca, incita, elude. Mesmo no momento de matar, a força que afunda a espada no corpo do touro deve ser também a da sua investida, e portanto essa "hora de la verdad" é o momento de mais perigo para o torero, porque sem o chamariz alternativo do pano, as hastes do touro vão dirigidas diretamente sobre seu corpo. O motivo mais comum de morte de toreros tem sido a perfuração da virilha, com hemorragia da artéria femoral. E, como Pitt-Rivers cuida de destacar, o torero não pode, nesse momento, tirar o corpo fora, usando a espada de lado, o que seria "assassinar o touro" e não matá-lo. A analogia desse momento culminante com uma cópula mortal, que às vezes pode ser recíproca, dispõe de muitos índices a partir dos quais se explicitar, embora a exegese nativa o evite discretamente.

É bom lembrar que, embora muito rara, existe a torera, e ela não é em absoluto uma inovação pós-moderna: já houve toreras no século XVIII Goya retratou alguma, nas suas gravuras de touradas - e, embora sua ação na arena, com o mesmo traje e a mesma prática, suscite opiniões contrárias entre os taurinos, ela não altera em absoluto o rito e o status de uma tourada. ${ }^{9}$

\footnotetext{
8 "Muito touro para pouco torero" é, por exemplo, um modo frequente de aludir à superioridade (uma superioridade "sexual") da mulher de um casal: é sempre o touro macho o usado como referência para a mulher nessas alegorias.

9 A mesma coisa pode se dizer a respeito da homossexualidade de um e outro torero, conhecida ou eventualmente assumida: ela não põe nenhum obstáculo simbólico ao papel desempenhado na festa.
} 
Já a substituição de um touro por uma vaca seria absolutamente impensável; os festejos com vacas estão a rigor fora da tauromaquia, e não incluem a morte do animal. O verdadeiro e insubstituível macho da tourada é o touro.

Manuel Delgado Ruiz (1986), no seu livro sobre as touradas, partiu das ideias de Pitt-Rivers para dar um passo mais nessa interpretação generizada da festa e fazê-la mais sociológica e mais política. Em lugar de um confronto paradigmático masculino/feminino, ele identifica na tourada profissional uma teoria implícita da socialização. O homem é um bruto sem domar, e sua domesticação, sua redução ao mundo do trabalho e da família fica por conta da mulher, que recorre para isso à sedução e à sexualidade; os instintos podem ser redirecionados para a (re)produção se há uma mulher em funções civilizadoras que se ocupe disso. O que pode ser visto na arena é a amplificação trágica desse processo: o progressivo desgaste da besta entre seduções e feridas. Para que a tourada aconteça, o touro deve morrer; para que a vida social aconteça, o homem deve também morrer enquanto touro. Vale a pena lembrar que esse homem é um proletário, urbano ou rural: com raras exceções, o torero surge desse meio, e a própria tourada na sua forma clássica - tourada a pé - significou, no século XVIII, o triunfo do protagonismo popular num universo festivo até então próprio da aristocracia, que realizava as touradas a cavalo. ${ }^{10}$

A interpretação de Delgado Ruiz não está muito longe de um discurso quase explícito entre as classes populares espanholas: ${ }^{11}$ formula uma associação simbólica que é, certo, a de uma cultura subalterna que está em franco retrocesso, em meio a vastas mudanças do mercado de trabalho, da instituição

10 As touradas a cavalo continuam a existir, mas são vistas pelos taurinos como um gênero “menor". E dentro das touradas "a pé" o cavaleiro permanece como uma figura vilificada, a do "picador", objeto preferido das vaias do público tão logo insiste na sua tarefa - um ponto destacado por Pitt-Rivers. Embora inflijam ao touro um sofrimento não menor, e representem um encontro muito mais desigual que o do toureio a pé, as touradas a cavalo figuram num discreto segundo plano das iras antitaurinas: conheci pessoas que não suportavam a ideia de presenciar uma tourada a pé, mas chegavam a apreciar uma tourada a cavalo, onde a beleza e a habilidade de um dos animais reduzia o outro a uma espécie de sombra ameaçadora...

11 Num artigo posterior de título provocativo (Delgado Ruiz, 2000), o autor indica que essa mesma alegoria aparece no romance Pamela, de Richardson, um autor do século XVIII inglês, que mostra a transição de um conceito da mulher como ser eminentemente pecaminoso a um conceito vitoriano (e de raiz calvinista) da mulher como civilizadora. Mas o romance de Richardson tem um final feliz, em que o "touro" acaba manso "como uma vaca". Seu inverso, com a mulher domesticadora tornada mulher fatal, poderia ser o célebre filme de Nagisa Oshima conhecido internacionalmente - também na Espanha - como O império dos sentidos. O título japonês do filme incluía uma palavra espanhola: Ai no korida (de corrida) - "tourada amorosa"; no cartaz japonês, a sombra de um touro se projetava sobre os amantes.

Horizontes Antropológicos, Porto Alegre, ano 23, n. 48, p. 151-170, maio/ago. 2017 
familiar e dos papéis de gênero. Embora nas polêmicas entre taurinos e antitaurinos os argumentos ligados ao gênero sejam muito secundários, essas últimas mudanças têm tido um papel de destaque na progressiva rejeição às touradas: essa mensagem implícita que sugerem Pitt-Rivers e Delgado Ruiz pode parecer tão intolerável como a própria festa que as codifica.

\section{Gênero e espécie}

Dentro de um seminário que tratou comparativamente das relações de gênero na Amazônia e na Melanésia, Marylin Strathern (2001, p. 226) incluiu uma formulação irretocável da sua tese de que o gênero não é uma superestrutura do sexo:

Men and women are sources of metaphors about maleness and femaleness, but in combination as well as separation, and this I take as the most interesting relationship between them.

Assim, os signos do masculino e do feminino não correspondem exclusivamente a homens e mulheres: são patrimônio de ambos, potências ativadas em função de relações concretas. No mesmo volume, as contribuições de alguns etnólogos como Descola (2001, p. 91-114) sugeriam um papel menor da dualidade de gênero nas sociedades amazônicas, ou a rigor seu englobamento pela oposição entre consanguinidade e afinidade. Ou seja, por uma relação com o Outro que se manifesta plenamente na caça, na guerra e no canibalismo (Viveiros de Castro, 2000) e que assim equaciona as relações de afinidade (e gênero) com as que se estabelecem entre espécies. Não por acaso, os dramas matrimoniais contados pelos mitos ameríndios enfrentam cônjuges humanos e animais. $\mathrm{O}$ argumento melanésio de Strathern poderia se estender assim à relação amazônica entre humanos e animais - se aproximando muito, desse modo, à definição lévi-straussiana do totemismo: a diferença entre as espécies, como a diferença entre os sexos, é uma fonte de metáforas para qualquer outra relação inter ou intragrupal. Não se trata tanto de oposição entre humanos e animais, mulheres e homens, mas entre potências que são ativadas dependendo da relação focada em cada momento.

Os meus comentários a respeito das touradas podem ser organizados de acordo com esse conjunto de ideias. A tourada coloca em cena os papéis de 
gênero, mas não - como poderia parecer à primeira vista - representados por homens e mulheres, senão como qualidades distribuídas entre um conjunto de atores que inclui todos os humanos e os animais implicados na festa. Do mesmo modo que o contraste entre animal e humano transcende os limites do encontro entre o touro e o humano para ser um sinal também da relação entre homens e mulheres. Os gêneros se opõem como espécies na mesma medida em que as espécies se opõem como gêneros.

Esse jogo é suscetível de múltiplas realizações de um canto a outro do planeta: a das touradas se distancia claramente dos modelos "melanésio" e "amazônico" aos quais acabo de aludir. A diferenciar as touradas do complexo da predação amazônica concorre especialmente o conceito de bravu$r a$, que deve ser completamente separado de noções como "selvagem" ou "natural". O touro bravo não é um animal "selvagem"; ele procede de um espaço aberto onde se cruzam a vida selvagem e a agricultura e sua própria agressividade é culturalmente induzida (veja-se infra, nota 15). A bravura faz parte de um inventário de virtudes - atribuídas ao touro - tipicamente humanista, fazendo par especialmente com a "nobreza". Por outro lado, as relações entre o ser humano e o touro não são percebidas como equivalentes a relações de afinidade/inimizade (como as que no modelo amazônico encarnam as diferentes espécies), pois é a filiação o que fica em destaque: o touro leva a marca do seu criador e, junto com seu nome próprio, cada touro é conhecido também pelo sobrenome desse criador: ele é "um Mihura", "um Vitorino". O touro bravo equidista entre o selvagem e o doméstico (como entre o consanguíneo e o afim): é um devir que parte do primeiro num movimento nunca completo ao segundo, e que nunca se resolve na domesticação. A bravura pode ser burlada pelas astúcias da arte, mas isso nunca transformará o touro em xerimbabo, ${ }^{12}$ nem as touradas em rodeio ou em circo.

Comparando as touradas com os rituais melanésios de Strathern (1988), é outro contraste o que vem à luz: nestes, a reprodução sexuada dos porcos é englobada no trabalho doméstico da mulher que por sua vez é englobado na ação ritual pública do homem: a culminação do processo é uma troca entre

12 Essa possibilidade aparece, no entanto, como milagre em alguns velhos rituais rurais como o do Touro de San Marcos (Caro Baroja, 1974). O touro vira, nesse aso, um “xerimbabo" do santo. 
homens. As touradas são, pelo contrário, fruto de um trabalho marcadamente masculino (lembre-se, como exemplo extremo, aquela função nutriz do vaqueiro de Monleón) e o feminino aparece em destaque precisamente no produto final, seja no aspecto feminino do matador, seja na presença de mulheres como destinatárias da morte do animal. A dualidade de gênero não se instala na produção da festa mas na sua consumação; não está na sua infraestrutura mas na sua expressão.

Num artigo sobre o universo simbólico do catolicismo rural espanhol (Calavia Sáez, 1997), eu mesmo tracei um contraste entre metáforas vegetais - as múltiplas aparições da árvore sagrada - e metáforas animais, quase todas elas taurinas. Quando não incompatíveis, esses dois conjuntos dividem seus domínios com nitidez, e o meu artigo correlacionava isso com diferenças ambientais (de um lado, a relação entre a aldeia e o bosque; do outro, a relação entre aldeias separadas por interstícios que incluem, é claro, as fazendas de criação do touro bravo), mas sobretudo com um registro sociológico. As metáforas "vegetais" acompanham representações do social em que a aliança e a própria sexualidade que a fundamenta são elididas, e a comunidade se postula como um corpo que se perpetua por si mesmo, como essas árvores sagradas que, real ou aparentemente, se reproduzem mediante algum modo de clonagem. Já no universo "do touro" as dualidades agônicas - entre comunidades vinculadas por alianças e inimizades tradicionais passam a primeiro plano, junto com a sexualidade que the serve como metáfora geral ou como pretexto histórico. Pensar vegetalmente aponta para a autoctonia, para a encenação ritual ou narrativa de um mundo endógamo, daquela famosa "doçura de viver entre si" de que Lévi-Strauss falou. Pensar animalmente aponta para a cisão, para o conflito. Para a sexualidade, na medida em que o sexo é a primeira das cisões humanas ou o motivo preferido de disputa.

O romance de Los mozos de Monleón, com que iniciamos a análise, tem a virtude de reduzir todo este último conjunto à sua mínima expressão, constituindo algo assim como o átomo da tauromaquia: a filiação cindida segundo gêneros (mãe/filho), a identidade cindida segundo espécies (humano/touro) e, mediando entre um lado e outro, essa aproximação entre gestação e morte. As touradas não apenas põem em jogo as dualidades mais básicas com que uma cultura pode ser construída, como o fazem nas versões mais fortes destas, e com a morte como mediadora - toda uma tragédia. 


\section{Sacrifício e tragédia}

Delgado Ruiz conclui seu livro falando da tourada como um dos raros exemplos de rito sacrificial que sobrevivem num mundo avesso ao próprio conceito de sacrifício. A identificação da tauromaquia como sacrifício, como Pitt-Rivers já percebeu, é uma constante dos trabalhos a respeito, ${ }^{13}$ muito mais como axioma que como argumento. Talvez não pareça necessário argumentar: a tourada é trágica, não dramática nem competitiva: o próprio termo "tauromaquia", - como o termo bullfight com que é conhecida em inglês - é uma péssima tradução. ${ }^{14} \mathrm{Na}$ tourada ninguém duvida sobre o desfecho, e deve ser o único espetáculo do presente ao qual se assiste sabendo que pelo menos um dos seus protagonistas morrerá. ${ }^{15}$ Nada de fundamental se altera - muito pelo contrário - nos casos em que o torero também morre. ${ }^{16}$ Por muito que a morte de um torero possa ser descrita na hora como um acidente indesejável, ela é uma culminação, um "sacrifício perfeito" por cima do sacrifício habitual. A glória suprema é a do torero morto na arena: os monumentos taurinos comemoram esse episódio. A morte do torero Paquirri galvanizou no começo dos anos 1980 uma festa que passava por um mau momento, e algo parecido aconteceu, mais recentemente, com as atuações temerárias de outro torero, José Tomás: as imagens que o mostravam continuando na lida totalmente ensanguentado correram mundo, e fizeram mais por manter o prestígio da festa que todas as declarações de patrimônio cultural.

E no entanto toda essa glosa sobre o sacrifício esbarra num problema léxico: as touradas não são "um sacrifício" em nenhum dos sentidos que esse termo tem em espanhol. Nada tem a ver com o sacrifício cristão: a teologia cristã conta com um sacrifício fundador que exclui doravante qualquer outro sacrifício independente, e se renova mediante um ritual, o da missa, visivelmente incruento. Sejam quais sejam os vínculos das touradas

13 Veja-se, para um caso de tauromaquia rural brasileira, a coletânea de Bastos (1993).

14 A má tradução é assumida pelos antitaurinos quando se referem, por exemplo, à vileza de uma luta desigual. "Esporte" poderia ser uma tradução ainda pior. "Arte" é a categoria preferida pelos taurinos, que exigiria outra discussão à parte.

15 Há uma possibilidade excepcional de indulto do touro que mostrou uma excelência muito além do comum: ele é então devolvido à fazenda como reprodutor.

16 As mortes de toreros na arena se tornaram raras no último meio século da festa; eram antes um destino final muito comum.

Horizontes Antropológicos, Porto Alegre, ano 23, n. 48, p. 151-170, maio/ago. 2017 
com o cristianismo, eles estão "ao lado": ninguém pretende ganhar o céu com elas. ${ }^{17} \mathrm{O}$ uso corriqueiro do termo "sacrifício" em espanhol é acintosamente dessacralizado: ou bem designa o abate utilitário de animais, ou aponta a noções de restrição, de austeridade, de poupança para algum investimento.

As touradas são um sacrifício apenas para os antropólogos, mas mesmo nesse caso falta também essa dimensão "vertical" que nas teorias clássicas faz do sacrifício o modo essencial de relação com a divindade. As touradas não servem para consagrar um poder religioso ou político, não produzem qualquer noção de totalidade social ou religiosa, não são um símbolo do Estado mesmo quando o chefe de Estado as preside: ele está "ao lado" também, em nenhum momento o foco da festa se desvia em sua direção.

A tourada, em geral, não produz: é claro que ela sustenta um enclave na economia espanhola, com alguns milhares de empregos vinculados às mil e uma destrezas exigidas para a criação do touro, a preparação dos trajes, o adestramento dos toreros e os mil e um ofícios de um espetáculo barroco; mas, globalmente, é uma festa muito dispendiosa que precisa de subsídios. As análises de Pitt-Rivers ou Delgado Ruiz, relevantes se pensarmos em alegorizações mútuas do ritual e a vida profana, se perderiam se quisessem se impor em termos de eficácia simbólica; ninguém espera obter das touradas algo assim como integração social, harmonia entre os sexos (em que pese a Pitt-Rivers) - ou uma válvula de escape à violência social, como já pretendeu alguma interpretação etológica canhestra. A melhor prova disso pode ser a dificuldade que os taurinos têm para encontrar argumentos favoráveis à sua festa que não se remetam à sua discutida estética: as touradas são um fim em si mesmas, não produzem mais nada.

Contudo, as touradas foram durante muito tempo, e para boa parte da população espanhola, um centro da vida, esse tipo de jogo absorvente de que Geertz falou, ou esse fato social total de Mauss. Um papel que só faz sentido se passarmos de entender o sacrifício como produção de algum tipo de efeito a entendê-lo, parafraseando Bataille (1949), como dispêndio final, como consumo último que coroa um sistema de produção, como coda destrutiva que

17 Em que pesem as pitadas de catolicismo popular espalhadas pelo meio taurino, e ao já citado aspecto sacralizante, as touradas não são um evento religioso, e a Igreja Católica foi a primeira instituição que tentou aboli-las. 
finaliza uma construção social. ${ }^{18}$ Uma sociedade está em mãos não de quem produz, mas de quem determina e controla seu modo supremo de consumo. As touradas, tão difíceis de encaixar em algum ramo de atividade - Arte? Esporte? Cultura? - se definem espontaneamente como a contra-atividade por excelência, elas são La Fiesta.

Outrora despercebidas entre tantos outros divertimentos que implicavam animais, as touradas passaram a atrair o interesse dos artistas e intelectuais europeus a partir de finais do século XVIII - quando começaram a se sobressair como um espetáculo de imolação gratuita, cada vez mais isolado no meio de um mundo justificado pela utilidade. No início do século burguês, as touradas representavam o escândalo de um povo que, em lugar de velhos heróis (reis e cortesãos) ou novos heróis (homens de ciência, intelectuais, empresários) cultuava matadores. Ou o de um país, obviamente atrasado na carreira do progresso, em que a máxima expressão do consumo público estava não em mãos de suas elites (como a ópera), mas cifrado numa festa popular - popular pelos seus protagonistas e pelo seu público. Foi, diga-se de passagem, a única "revolução" chegada a termo num país cujas estruturas de poder permaneceram imutáveis: a nação passou a ser simbolizada por um festejo popular, no qual foram se condensando todos os dilemas e as aporias. Não é que as relações de gênero tivessem que recorrer às touradas para se exprimir ou para se equilibrar simbolicamente; foram as touradas que incorporaram o imaginário do gênero no mesmo movimento em que iam incorporando o do conflito político (a guerra civil como tauromaquia), o da religião (o cristianismo como religião de morte), ou a própria descrição geográfica do país (a península Ibérica como uma "pele de touro"). A tourada foi capaz de significar tudo, antes de tornar-se, para boa parte da sensibilidade contemporânea, um ritual sem sentido.

O discurso sobre as touradas tem insistido em vê-las como a expressão - sublime ou lamentável - de um país trágico. Mas creio que esse discurso deveria se inverter: nada na cultura espanhola indicava um gosto pela tragédia até que as touradas forneceram essa clave de interpretação para uma história nem mais nem menos trágica que outras. ${ }^{19}$

18 Os comentários sobre a tauromaquia de Leiris (2001) flertam nesse sentido com as ideias de Bataille, sem chegar a assumir a relação, o que, de resto, seria a tônica do encontro entre ambos os autores (Giobellina Brumana, 2014).

19 Num exame da literatura clássica espanhola chama a atenção a ausência quase total do gênero "tragédia", 


\section{Controvérsia}

Apesar do que disse pouco antes, os taurinos vêm ensaiando argumentos novos para além dos exauridos apelos à estética e à tradição, e dentre eles merecem destaque os ecológicos: os taurinos argumentam que é o negócio das touradas o que sustenta grandes áreas de bioma "nativo" na península, as dehesas em que os rebanhos de gado bravo são criados no meio de uma vegetação de sobreiros e azinheiras e de uma ampla fauna selvagem. Eventualmente fazem contrastar a vida em liberdade das manadas de bravos (garantida pela morte violenta da maior parte de seus machos) com o tratamento do gado pela indústria da carne, e costumam provocar os adversários dizendo que seus argumentos só seriam válidos em boca de vegetarianos. Os antitaurinos entendem tudo isso como sofismas repugnantes: o espetáculo cruel não tem sequer a desculpa utilitária de granjas e matadouros, e quanto à preservação ambiental espera-se, talvez ingenuamente, que ela seja assumida pelo Estado, mantendo essas áreas junto com o próprio gado de lidia.

Os taurinos têm divulgado também - num contexto em que ganha novas conotações - uma velha tese dos seus eruditos: o touro de lidia não é uma raça natural, mas criada por uma seleção humana; e é como resultado dessa manipulação cultural que o touro possui uma natural agressividade. ${ }^{20} \mathrm{O}$ corolário disso é claro, embora não necessariamente explícito: mesmo se não pode se dizer que ele escolha esse destino, o touro não é uma vítima passiva, ele tem uma intencionalidade, ele "quer" atacar (embestir). Os antitaurinos têm se virado também para esse aspecto da questão, repudiando o discurso da agressividade natural - e de quebra o da criação cultural. Quanto à investida

tão importante em outras literaturas europeias; um efeito, provavelmente, do zelo de um cristianismo incompatível com o caráter irresolúvel da tragédia. A primeira "tragédia espanhola" foi a rigor obra de autores franceses: a ópera Carmen - tão elogiada por Nietzsche - na qual a tourada aparece como ambiente mas também como uma espécie de roteiro oculto: a protagonista é apunhalada pelo seu amante enquanto o touro morre lá perto, na arena (Huebner, 1993).

${ }^{20}$ Uma parte essencial da criação de gado bravo consiste na seleção dos reprodutores mediante touradas incruentas realizadas numa pequena arena dentro da fazenda (as tientas) em que toreros profissionais ou amadores testam a "bravura" de uma seleção de touros. Os mais "bravos" - um conceito complexo que não significa apenas agressividade - são destinados a sementais, e os outros, sacrificados a seguir, porque depois de maleados não servem mais para a tourada.

Horizontes Antropológicos, Porto Alegre, ano 23, n. 48, p. 151-170, maio/ago. 2017 
do touro, ela é interpretada como uma reação apavorada aos apupos de uma multidão ensandecida. ${ }^{21}$

Mas o que os animalistas enfrentam nesse caso não é alguma versão da dicotomia cultura/natureza, ou da reificação do animal, como poderia acontecer nas polêmicas com as vivisseções, o uso de animais em testes científicos, a indústria da carne ou da pele. Nada impede que o entusiasta das touradas seja, no resto do tempo, um devotado protetor dos animais. De fato, no mundo taurino - e excetuando-se, é claro, a crueldade da morte - o tratamento do touro está a um mundo de distância do que se reserva ao gado de corte, e muito perto do que se reserva a um animal de estimação, até de uma estimação em grau supremo. Cada touro tem um nome pessoal junto ao sobrenome da sua ganadería. A retórica das touradas se excede tratando de sua beleza e sua bravura, dedicam-se lhe canções sentimentais em que com frequência se fala dele com um diminutivo afetuoso - el torito - e ao touro morto se reserva, em alguns casos, a mesma honraria que ao torero, dar a volta à arena entre aplausos e aclamações (certo que ele dá essa volta arrastado por umas mulas). O eventual indulto de um touro talvez constitua o momento mais emotivo que pode acontecer numa tourada. No outro extremo, os touros que mataram um torero têm seu nome perpetuado junto ao deste. Frente à praça de touros de Linares, onde em 1948 Manolete, talvez o torero mais emblemático do século XX, foi morto por Islero, levanta-se uma estátua de bronze dedicada... ao touro. Há outra, num lugar mais discreto, dedicada a Manolete. De fato, esse público que acode à praça para ver o touro ser ferido com lanças, arpões e espadas, possui no entanto um conceito peculiar da diferença entre isso e a tortura, e pode chegar a reagir com certa violência contra quem ultrapassa, por prazer ou por torpeza, essa fronteira. Isso certamente não comove os animalistas, que entendem toda essa subjetivação do touro não como um matiz, senão como um refinamento na barbárie. A virulência da controvérsia se acirra pela proximidade entre alguns aspectos da sensibilidade de seus contendentes.

${ }^{21}$ Isso denota uma ignorância real ou tática do que acontece numa praça de touros, onde a situação básica é de silêncio, quebrado em momentos especiais por músicas, aclamações, assobios ou vaias. Uma das situações em que as vaias proliferam é quando o touro não ataca (embiste) e fica indiferente às provocações, o que acontece com uma certa frequência. Mas nesse caso o objetivo não é exasperar o touro, mas exigir sua substituição; o touro então é retirado e sacrificado pelos métodos habituais de um matadouro.

Horizontes Antropológicos, Porto Alegre, ano 23, n. 48, p. 151-170, maio/ago. 2017 
De todas as abominações (reais e simbólicas) que a sensibilidade animalista poderia conceber, a tourada é a pior, precisamente em função dessa aproximação. Taurinos e animalistas têm muito em comum: jogam com um conjunto muito parecido de relações, organizadas em sentidos opostos. Refirome a esse cruzamento entre o contraste sexual e o contraste entre espécies, e às noções a respeito da morte. Dentro desse conjunto de noções comuns, a tourada se situa num polo diametralmente oposto ao tipo mais comum de animalismo. Este (vejam-se as etnografias de Segata, 2012 e Pastori, 2012) se foca nas capacidades e nas sensibilidades comuns a humanos e animais: isso permite que o divisor seja borrado, e os animais integrados como membros da família. A diferença entre humano e não humano é substituída por uma diferença de grau no exercício da humanidade: os animais de estimação entram nessa família como filhos, identificados como crianças e como tais tutelados. E se a sexualidade foi, dentro das tradições humanistas, um recordatório da animalidade que persistia no seio da condição humana, não poderia estranhar que ela seja excluída dessa humanização para além dos limites da espécie: o animal de estimação, esse novo filho da família humana, é, por excelência, um animal castrado.

Há muitos motivos, simbólicos e práticos, pelos quais o animal-criança precisa ser castrado. A sexualidade em si representa um dualismo equipolente e anti-hierárquico: para que se instaure a assimetria na relação entre os sexos é necessário conceituar um deles como menor de idade, como irmão mais jovem ou mesmo (lembremos da costela de Adão) como uma espécie de filho. Mas esses supostos são sistematicamente desafiados pela irrupção da atividade sexual: não é de outro modo no caso dos animais de estimação, que se tornam intratáveis ou incontroláveis por causa do cio - ameaçando ainda com a formação de uma população semisselvagem de animais "de rua".

A castração não é para os animalistas um detalhe, nem uma medida egoísta para a comodidade dos donos: insistem nela como um bem para o animal, que com ela evita uma série de doenças e tem uma vida mais longa. Essa castração não é vista como atentado à sua integridade: faz parte da mesma preocupação pelo controle de riscos que interessa também aos humanos.

Que a castração seja vista como garantia de um prolongamento da vida aponta também a noções menos explícitas sobre a vida e a mortalidade. Afinal, a relação entre a sexualidade e a morte, que as touradas evocam do modo mais acintoso, não é apenas uma tese psicanalítica, nem uma obscura imagem 
poética: ela é parte do cânone da biologia evolucionista, que nos diz que a separação de sexos faz sentido para seres efêmeros que, como espécie, podem se beneficiar de uma rápida recombinação genética.

Bom para a espécie, péssimo para os seus indivíduos. A civilização da que os animalistas fazem parte não nega (longe disso) a sexualidade. Mas a sexualidade deve ser função da subjetividade, uma fruição e uma forma de sociabilidade livre. A biotecnologia, em suas diversas expressões, dissolve seu vínculo necessário com a reprodução, e de quebra com a morte. Os projetos mais alvissareiros dessa biotecnologia apontam para variações da clonagem humana que, num mesmo movimento, tirariam de cena a sexualidade e a morte como fatalidades da existência humana. Por vertiginosa que seja, essa perspectiva não é mais impensável e, o que é mais importante, parece desejável para uma parcela crescente da população. A tauromaquia nunca foi um expoente da tradição, ou um arcaísmo sobrevivente: antes disso, ela subverteu ordens simbólicas anteriores, quando o torero ocupou o centro de uma areia onde antes os aristocratas encenavam a cavalo o domínio. Mas, com sua celebração da sexualidade e da morte do humano e do animal, tornou-se afinal o signo do passado frente a um hiper-humanismo que aspira a superar essas condições levando os animais (alguns animais, pelo menos) consigo.

Mas a polêmica taurina pode ser uma dessas disputas em que, imperceptivelmente, dois se atracam contra um, porque os taurinos estão longe de negar esse credo contemporâneo que condena o seu espetáculo preferido. Os animalistas desafiam essa dualidade natureza-cultura fundadora da civilização ocidental, e o fazem em nome da sua superação pela cultura: para o animal não humanizado restariam reservas naturais - que mesmo assim contam com justificações recreativas e educativas, e controlam os seus habitantes com pulseiras eletrônicas. Os taurinos, da sua parte, levantam a bandeira de uma visão trágica da vida, mas dificilmente a endossam longe da tourada. Lá, no mundo profano, é bem mais provável que em sua maioria adiram a esse mesmo credo hiper-humanista dos seus adversários que aspira ao cancelamento do que há de animal na condição humana. Para eles, as touradas teriam o mesmo papel que as reservas naturais têm para os animalistas: um enclave para a preservação, longe das relações efetivas, de uma dimensão outra do mundo, significativa mas impossível de assumir. 


\section{Referências}

BASTOS, R. J. de M. (Org.). Dioniso em Santa Catarina: ensaios sobre a farra do boi. Florianópolis: UFSC, 1993.

BATAILlE, G. La part maudite. Paris: Éditions de Minuit, 1949.

CALAVIA SÁEZ, O. Naturaleza, religión y cultura tradicional. Revista de Dialectología y Tradiciones Populares, Madrid, v. 53, p. 134-176, 1997.

CARO BAROJA, J. El toro de San Marcos. In: CARO BAROJA, J. Ritos y mitos equívocos. Madrid: Istmo, 1974. p. 77-110.

COSSIO, J. M. Los toros. Madrid: Espasa Calpe, 2007. 30 v.

DELGADO RUIZ, M. De la muerte de un dios: la fiesta de los toros en el universo simbólico de la cultura popular. Barcelona: Península, 1986.

DELGADO RUIZ, M. La administración de las pasiones. El torero como heroína sexual calvinista. Revista de Estudios Taurinos, Sevilla, n. 12, p. 53$70,2000$.

DESCOLA, P. The genders of the gender: local models and global paradigms in the comparison of Amazonia and Melanesia. In: GREGOR, T. A.; TUZIN, D. (Ed.). Gender in Amazonia and Melanesia: an exploration of the comparative method. Berkeley: University of California Press, 2001. p. 91-114.

GIOBELLINA BRUMANA, F. El lado oscuro: la polaridad "sagrado/profano" y sus avatares. Buenos Aires: Katz, 2014.

HUEBNER, S. Carmen as "corrida de toros". Journal of Musicological Research, New York, v. 13, n. 1-2, p. 3-29, 1993.

LEIRIS, M. Espelho da tauromaquia. São Paulo: Cosac \& Naify, 2001.

PASTORI, É. O. Perto e longe do coração selvagem: um estudo antropológico sobre animais de estimação em Porto Alegre, Rio Grande do Sul. 2012. Dissertação (Mestrado em Antropologia Social)-Instituto de Filosofia e Ciências Humanas, Universidade Federal do Rio Grande do Sul, Porto Alegre, 2012. 
PITT-RIVERS, J. El sacrificio del toro. Revista de Occidente, Madrid, n. 36, p. 27-47, 1984.

PITT-RIVERS, J. El sacrificio del toro. Revista de Estudios Taurinos, Sevilla, n. 14, p. 77-118, 2002.

PUERTO, J. L. Los mozos de Monleón: oscura tragedia ritual. Revista de Folklore, Valladolid, n. 95, p. 154-159, 1988.

SEGATA, J. Nós e os outros humanos, os animais de estimação. 2012. Tese (Doutorado em Antropologia Social)-Centro de Filosofia e Ciências Humanas, Universidade Federal de Santa Catarina, Florianópolis, 2012.

STRATHERN, M. The gender of the gift: problems with women and problems with society in Melanesia. Berkeley: University of California Press, 1988.

STRATHERN, M. Same sex and cross-sex relations. Some internal comparisons. In: GREGOR, T.; TUZIN, D. Gender in Amazonia and Melanesia: an exploration of the comparative method. Berkeley: University of California Press, 2001. p. 221-244.

TILLION, G. Il était une fois l'ethnographie. Paris: Éditions du Seuil, 2000.

VIVEIROS DE CASTRO, E. Atualização e contra-efetuação do virtual na socialidade amazônica: o processo do parentesco. Ilha: Revista de Antropologia, Florianópolis, v. 2, n. 1, p. 5-46, 2000. 